conditions identified in the environmental impact assessment may be also result of serious consequences.

In view of the above, the article concludes that it is inappropriate to use a banquet form to determine the disposition of this category of criminal offenses. It is emphasized that the Criminal Code of Ukraine should provide for a separate special article on crimes in the field of environmental impact assessment. It should be called "Violation of the requirements of the legislation on environmental impact assessment" and include the following types of offenses: 1) failure to take into account in a prescribed manner the results of the environmental impact assessment when deciding to carry out the planned activity; 2) preparing a deliberately false opinion on environmental impact assessment; 3 ) carrying out the planned activity subject to the environmental impact assessment without carrying out such assessment and obtaining the decision on the implementation of the planned activity; 4) non-observance during the economic activity, operation of objects, other interventions in the natural environment and landscapes, including the extraction of minerals, the use of man-made mineral deposits, environmental conditions, determined in the conclusion of the environmental impact assessment, decisions on carrying out the planned activity.

Keywords: criminal liability, crime in the field of environmental impact assessment, violation of the procedure of environmental impact assessment, environmental safety.

DOI: $10.33766 / 2524-0323.89 .79-89$

УДК 343.322

О. В. Зайщев,

кандидат юридичних наук, доцент, доцент кафедри кримінального права № 1 Національного юридичного університету України імені Ярослава Мудрого (м. Харків, Україна) e-mail: tavr0106@gmail.com iDhttps:/ / orcid.org/0000-0002-6743-7114

\title{
ПРОБЛЕМИ КВАЛІФІКАЩЇ ДЕРЖАВНОЇ ЗРАДИ НА СУЧАСНОМУ ЕТАПІ
}

На підставі вивчення судової практики Касаційного кримінального суду в складі Верховного Суду зроблено висновок про різну кримінально-правову оцінку збройних конфліктів на території України. Це спричиняе застосування, ст. 111 КК України, в одному випадку, і ст. 258-3 КК України - в іншому. Приділено увагу міжнародній правовій оцінці збройних конфліктів на території України. Наголошується на значенні проваджень Міжнародного кримінального суду, рішення якого здатні вплинути на розв'язання проблем кваліфікації державної зради.

Ключові слова: державна зрада, збройний конфлікт, Міжнародний кримінальний суд.

Постановка проблеми. Вивченню злочинів проти основ національної безпеки України, зокрема державної зради, у науці кримінального права України тривалий час не приділялося значної уваги. Це пояснюється тим, що цей злочин вчинявся вкрай рідко [1], відповідно й емпірична база для дослідження була майже відсутня. Через те не дивно, що основні грунтовні дослідження були проведені ще радянськими вченими, у тому числі за результатами кримінальних проваджень під час

(С) Зайцев О. В., 2020 
Другої Світової війни. Наприклад, у 1941 р. за ст. 58-1б КК Російської Радянської Федеративної Соціалістичної Республіки «Зрада Батьківщині» було засуджено 8976 військовослужбовців, у 1942 р. - 45 050, у 1943 р. - 527 57, у 1944 р. - 69895 осіб [2]. Надалі, після завершення «холодної війни», між Радянським Союзом і його союзниками, з одного боку, та США і країнами Західної Свропи і їхніми союзниками - 3 іншого, що призвело до розпаду СРСР, проблематика державної зради в Україні не була актуальною, а тому й не викликала інтересу для дослідників-криміналістів.

Ситуація різко змінилася, коли в Україні відбулася Революція гідності, тимчасова окупація Автономної Республіки Крим (далі - АР Крим) [3] та територій у Донецькій та Луганській областях [4]. Саме з 2014 р. кількість кримінальних проваджень за ст. 111 КК України зросла в десятки разів. Так, згідно з повідомленням Служби безпеки України, за матеріалами Департаменту контррозвідки, тільки в 2019 р. розпочато 239 кримінальних проваджень за злочини проти основ національної та громадської безпеки, зокрема за ст. 111 КК України - 57 проваджень. Завдяки діяльності контррозвідки до різних видів та строків покарання за державну зраду засуджено 24 особи [5].

Водночас, більшість обвинувальних вироків була або ще перебуває на стадії апеляційного чи касаційного оскарження. Доводи в скаргах осіб, які є обвинуваченими в державній зраді, та їх захисників різноманітні. Низка з них, зокрема щодо неправильного застосування закону України про кримінальну відповідальність, заслуговують на вивчення й аналіз через призму законодавства України та практики.

Аналіз останніх досліджень і публікацій. Питання державної зради досліджувалися в коментарях до КК України, посібниках, підручниках з Особливої частини кримінального права та окремих наукових статтях. Зокрема, ці питання висвітлювали у своїх працях М. І. Бажанов, О. Ф. Бантишев, Ю. В. Баулін, І. В. Діордіца, Л. М. Демидова, 3. А. Загиней, Н. С. Кончук, В. А. Ліпкан, Ю. В. Луценко, М. І. Мельник, Л. В. Мошняга, М. А. Рубащенко, В. Я. Тацій, В. П. Тихий, М. І. Хавронюк, Р. Л. Чорний, О. В. Шамара, В. М. Шлапаченко та ін.

Формулювання цілей. Метою статті $є$ аналіз проблем, які виникають при встановленні ознак державної зради на сучасному етапі історії України. Для цього слід вивчити доступну судову практику за 2014-2019 рр., зокрема, Касаційного кримінального суду в складі Верховного Суду. Також слід приділити увагу міжнародно-правовій оцінщі збройних конфліктів на території України, особливо матеріалам звітів Канцелярії Прокурора Міжнародного Кримінального Суду за 2016 р., 2018 р. та 2019 р.

Виклад основного матеріалу. Вивчення судової практики дозволяє виділити низку проблем кримінально-правової кваліфікації державної зради, причому за всіма трьома формами їі об’ єктивної сторони [6, 7]. Приділимо увагу найбільш дискусійним їх аспектам.

В Україні у 2014 року розпочалися два збройні конфлікти - на території АР Крим і в окремих районах Донецької та Луганської областей [8]. Водночас Єдиний державний реєстр судових рішень України містить інформацію виключно про обвинувальні вироки за ст. 111 КК України щодо осіб, які вчинили перехід на бік ворога в період збройного конфлікту України та Російської Федерації (далі - РФ) на 
території АР Крим. Жодного обвинувального вироку за державну зраду при переході на бік ворога під час збройного конфлікту на території окремих районів Донецької та Луганської областей немає.

Виходячи з текстів судових рішень, такий підхід органів кримінальної юстиції має певне пояснення. Суди вказують на відсутність міждержавного збройного конфлікту на сході України, на відміну від наявності його ознак на території АР Крим. Також зазначається, що території Донецької та Луганської областей не мають статусу тимчасово окупованих РФ. Крім того, судді звертають увагу на сутність «Донецької народної республіки» як терористичної організації, яка не містить жодних ознак, притаманних державі. Указане «утворення» не визнається як держава ані Україною, ані будь-якими іншими державами або міжнародними організаціями. Не менш вагомим, на думку суддів, є відсутність доказів того, що громадянин України перейшов на бік саме РФ, з якою Україна офіційно не перебуває ані в стані війни, ані в стані збройного конфлікту [9].

Такий підхід призвів до того, що дії громадян України з надання представникам «ДНР» та/чи «ЛНР» допомоги в проведенні підривної діяльності проти України або переходу на їх бік кваліфікуються, як правило, за ст. 258-3 КК України. Додатковим аргументом для такої кримінально-правової кваліфікації став висновок колегії суддів Другої судової палати Касаційного кримінального суду в складі Верховного Суду, згідно 3 яким для притягнення особи до кримінальної відповідальності за ст. 258-3 КК України не вимагається «існування окремого судового рішення, рішення органу законодавчої чи виконавчої влади про визнання діяльності терористичною» [10].

Утім кваліфікація дій громадян України при переході на бік «ДНР» та «ЛНР» може невдовзі змінитися. Пов' язане це з тим, що, по-перше, з 30.06.2019p. набрала чинності ч. 6 ст. 124 Конституції України, відповідно до якої «Україна може визнати юрисдикцію Міжнародного кримінального суду на умовах, визначених Римським статутом Міжнародного кримінального суду». По-друге, збройний конфлікт на сході України є предметом вивчення Канцелярією Прокурора Міжнародного кримінального суду, яка, за результатами попереднього розслідування, опублікувала звіт за 2016 р. У висновках зазначається, що до 30 квітня 2014 року інтенсивність бойових дій між українськими урядовими військами й антиурядовими озброєними елементами на сході України досягла такого рівня, який тягне за собою можливість застосування до нього права збройних конфліктів, і що озброєні групи, які діють на сході України, у тому числі «ЛНР» та «ДНР», достатньо організовані, щоб вважатися сторонами неміжнародного збройного конфлікту.

Канцелярія Прокурора також дійшла до висновку, згідно з яким приклади прямого збройного протистояння між збройними силами РФ та України вказують на те, що принаймні з 14 липня 2014 року на сході України, паралельно із неміжнародним збройним конфліктом, має місце міжнародний збройний конфлікт. Канщелярія Прокурора продовжує розглядати заяви про те, що РФ здійснювала та здійснює загальний контроль над озброєними групами на сході України задля визнання існуючого збройного конфлікту між Збройними Силами України (далі 3СУ) та антиурядовими озброєними групами по суті міжнародним. Факт існування єдиного міжнародного збройного конфлікту на сході України передбачає вжиття щодо відповідного періоду статей Статуту, який стосується збройних конф- 
ліктів міжнародного характеру [11]. 05 грудня 2018 р. Канцелярія Прокурора надала звіт по попередньому розслідуванню конфлікту на сході України за 2018 р., який містить висновки, ідентичні звіту за 2016 р. [12]. У звіті ж за 2019 рік наводиться висновок Канцелярії Прокурора, що прямі військові дії між відповідними збройними силами Російської Федерації та Україною свідчать про існування міжнародного збройного конфлікту на сході України не пізніше 14 липня 2014 року, паралельно із неміжнародним збройним конфліктом [13].

Отже, визнання Міжнародним кримінальним судом збройного конфлікту в окремих районах Донецької та Луганської областей міжнародним (між Україною та РФ) стане додатковим аргументом кваліфікації дій громадян України (за наявності інших ознак складу злочину) за ст. 111 КК України.

Наступною проблемою при кваліфікації злочину, передбаченого ст. 111 КК України у формі переходу на бік ворога в період збройного конфлікту є вказівка на відсутність збройного конфлікту на території АР Крим або завершення періоду його існування [14]. Окремі аспекти цього питання вже були розглянуті раніше [15]. На додаток до сформованих висновків щодо існування міждержавного збройного конфлікту, вважаємо за необхідне враховувати прийняття Генеральною Асамблею ООН низки резолюцій, які стосуються окупації АР Крим, під час здійснення кримінально-правої кваліфікації. Зокрема, Резолюція Генеральної Асамблеї ООН «Територіальна цілісність України» від 27 березня 2014 р. № 68/262; Резолюції «Ситуація з правами людини в АР Крим та м. Севастополь, Україна» від 19 грудня 2016 p. № 71/205; від 19 грудня 2017 р. №71/205; від 22 грудня 2018 р. № 73/263; від 19 грудня 2019p. № 74/168; Резолюції «Проблема мілітаризації АР Крим та м. Севастополь (Україна), а також частин Чорного й Азовського морів» від 17 грудня 2018 р. № 73/194; від 9 грудня 2019p. № 74/17.

Кожна 3 цих резолюцій має суттєве значення для правильної оцінки збройного конфлікту на території АР Крим, та, відповідно, і для правильного і точного встановлення об'єктивних ознак державної зради. Зокрема, у Резолюції № 68/262 Генеральна Асамблея ООН зазначила, що т. зв. «референдум» 16 березня 2014 року $є$ незаконним і не може стати основою для будь-якої зміни статусу АР Крим або міста Севастополя, та закликала всі держави, міжнародні організації та спеціалізовані установи не визнавати будь-якої зміни статусу АР Крим та міста Севастополя на основі згаданого вище «референдуму». У подальших резолюціях, починаючи із Резолюції від 19 грудня 2016 р. № 71/205, РФ визнається державоюокупантом, а територію Криму і Севастополя - тимчасово окупованими територіями. Слід зауважити, що в Резолюції від 19 грудня 2017 р. № 71/205 державипідписанти закликали РФ дотримуватися норм міжнародного гуманітарного права, зокрема Женевських конвенщій 1949 р. і Додаткового протоколу № 11977 р. до них. Враховуючи те, що вказані угоди стосуються законів і звичаӥв війни, спрямовані на захист жертв збройних конфліктів, це дозволяє зробити висновок, що Генеральна асамблея ООН опосередковано визнає наявність міжнародного збройного конфлікту за участю РФ. Усі вищезгадані резолющії підтверджують єдність і територіальну цілісність України в межах іiі міжнародно визнаних кордонів і засуджують незаконну анексію, а також вимагають дотримання окупаційною владою всіх своїх зобов' язань згідно із міжнародним правом. 
Слід навести результати попереднього розслідування злочинів, що вчинені на території АР Крим, яке здійснює Канщелярія Прокурора Міжнародного кримінального суду. Звіти за 2016 р., 2018 р., 2019 р. [11-13] кваліфікують ситуацію на території Криму та Севастополя як міжнародний збройний конфлікт між Україною та РФ, який виник не пізніше 26 лютого 2014 р. Причому право міжнародних збройних конфліктів повинно бути застосовано і після 18 березня 2014 р., через те що в Криму та Севастополі фактично зберігається стан окупації, а, згідно із законодавством України, дата окупації півострова - 20 лютого 2014 р. [3]. Таким чином, наведені нормативні акти та звіти вказують на те, що міжнародний збройний конфлікт у Криму триває й надалі у виді окупації півострова.

У зв'язку з викладеним, звертають на себе увагу такі факти. Прийняття резолюцій Генеральної асамблеї ООН та оприлюднення Канцелярією Прокурора Міжнародного кримінального суду звітів про дії з попереднього розслідування злочинів, які вчинені на території України, призвели до відповідної реакції з боку РФ. 16 листопада 2016 р. Президент РФ підписав розпорядження «Про наміри Російської Федеращії не стати учасником Римського Статуту Міжнародного кримінального суду» [16]. Надалі ж РФ взагалі вийшла з Женевської конвенції про захист цивільного населення під час міжнародних збройних конфліктів. Закон «Про відкликання заяви, зробленої при ратифікацію Додаткового протоколу до Женевських конвенщій від 12 серпня 1949 р., щодо захисту жертв міжнародних збройних конфліктів (Протокол I)» підписаний Президентом РФ 12 листопада 2019 р. [17].

Окрім вищевикладеного, під час вивчення судової практики виявлено, що однією з підстав оскарження обвинувальних вироків за ст. 111 КК України є доводи захисників про відсутність ознак суб'єкта цього злочину. Як приклад, можна навести кримінальне провадження щодо військовослужбовця Збройних Сил України, який ілюструє поширений і характерний випадок вчинення державної зради під час російської агресії на території АР Крим. Так 22 березня 2014 року цивільними особами та військовослужбовцями РФ відбулося захоплення військової частини ЗСУ, яка дислокована у смт. Новофедорівка Сакського району АР Крим. Через незаконне захоплення зазначеними особами зброї та боєприпасів бойова та мобілізаційна готовність військової частини була підірвана.

В один із днів третьої декади березня 2014 року командуванням частини на загальному шикуванні доведено до всього особового складу ситуацію в АР Крим та необхідність прийняття рішення кожним військовослужбовцем щодо дотримання Військової присяги на вірність Українському народові й передислокації особового складу частини на материкову частину України для подальшого проходження військової служби в ЗСУ. Однак білышість військовослужбовців самовільно залишили військову частину та звернулись із рапортами до командування Чорноморського флоту РФ із проханням зарахувати їх в ряди Збройних Сил Російської Федеращії та заявами про прийняття громадянства РФ.

Однією із таких осіб став прапорщик цієї частини, який відмовився виконувати обов 'язки несення військової служби в ЗСУ та заявив про намір проходити службу в Збройних Силах РФ. Причому, ще до силового захоплення військової частини, а саме 20 березня 2014 року, він уклав контракт строком на 1 (один) рік про проходження військової служби й зарахування в списки особового складу Збройних Сил РФ як повітряний радист авіаційної ланки змішаної авіаційної ескадрильї змішаного авіаційного полку. 
Як наслідок, ним були проігноровані вимоги Командувача Військово-Морських Сил ЗСУ від 24 квітня 2014p. про передислокацію військовослужбовців військових частин із півострову Крим до визначених місць знаходження на континентальній частині України. Не виконав він також наказ від 12 травня 2014 р. про здійснення маршу особового складу військової частини 3 місця дислокації військової частини в АР Крим до м. Миколаїв [18].

Під час судового розгляду захисник наполягав на відсутності ознак суб'єкта злочину, а саме громадянства України підсудного. Це свідчило, на думку адвоката, про неможливість здійснювати підсудним військову службу в ЗСУ після 18 лютого 2014 року. I, відповідно, у період збройного конфлікту України і РФ, початком якого є 26 лютого 2014 року, він не був військовослужбовцем ЗСУ, а на момент вступу на військову службу за контрактом до Збройних Сил РФ уже був громадянином РФ [19].

Позищію сторони захисту, що підсудний не був громадянином України і не був військовослужбовцем ЗСУ на момент захоплення штабу військової частини, суд не взяв до уваги. Оцінюючи факт отримання підсудним 2 квітня 2014 року паспорта громадянина РФ, суд зазначив, що згаданий прапорщик є громадянином саме України, а підтвердженням для такого висновку є наявність у нього паспорта громадянина України, що, відповідно до положень Закону України «Про громадянство України», свідчить про наявність громадянства нашої держави. Верховний Суд колегією суддів Другої судової палати Касащійного кримінального суду залишив без змін вирок районного суду та ухвалу апеляційного суду, а касаційну скаргу захисника - без задоволення [20].

У контексті цього кримінального провадження наведемо цікавий факт. У вересні 2016 р. Генеральна прокуратура РФ надіслала до Генеральної прокуратури України лист, у котрому наполягала на відсутності громадянства України в сотень підозрюваних за ст. 111 КК України, які вчинили перехід на бік РФ під час збройного конфлікту в АР Крим. Основним аргументом наводився текст так званого Указу Президента України «Про вихід із громадянства України» від 21 березня 2014 р. № 01/2014, який підписав В. Ф. Янукович, перебуваючи в м. Ростов-на-Дону [21].

Цей документ та йому подібні не визнаються органами державної влади України як офіційні. Відповідно, і наведене вище рішення Верховного Суду має суттєве значення під час розгляду наступних кримінальних проваджень. Особливо враховуючи те, що, згідно із заявою в. о. президента України (з 22.02.2014p. по 07.06.2014p.) О. Турчинова, «серед усіх силовиків, які перебували в Криму, незрадили свою країну: з 13468 солдатів та офіцерів Збройних сил - лише 3990 (29,6%); 110936 працівників MBC не стали зрадниками лише 88 осіб (0,8 \%!); з 1870 прикордонників до України повернулося лише 519 (29,7 \%); з 2240 працівників СБУ - лише 242 (10,8 \%); із 527 офіцерів і прапорщиків Управління держохорони не зрадили Україну лише 20 осіб» [22] Слід додати, що й досі тривають провадження за ст. 111 КК України проти 327 суддів, 299 працівників прокуратури, 134 депутатів Севастопольської міськради та ВР АРК, 11 самопроголошених представників влади Криму [23].

Висновки. Аналіз окреслених у цій статті проблем кваліфікації державної зради на сучасному етапі історії України не є вичерпним. Діяльність органів кримінальної юстищії поступово виявляє нові труднощі в правозастосовчій практищі, 3 якими стикаються учасники кримінальних проваджень за ст. 111 КК України. Значне коло гостро дискусійних питань може бути вирішено за підсумками діяльності 
Міжнародного кримінального суду, який остаточно встановить наявність чи відсутність на території України збройних конфліктів, їх характер, сторони, період існування та інші правові наслідки. До цього ж часу учасники кримінального провадження, обираючи і застосовуючи норму закону України про кримінальну відповідальність про державну зраду, повинні враховувати наявні висновки Касаційного кримінального суду, які викладені в постановах Верховного Суду.

\section{Використані джерела:}

1. За 10 років в Україні за державну зраду засудили 7 людей. 28.04.2012. URL: http:// tyzhden.ua/News/48897

2. Сколько «изменников» обнаружила Родина № 103, 16.09 .2011 https:// novayagazeta.ru/articles/2011/09/16/45916- skolko-171- izmennikov-187- obnaruzhila-rodina

3. Про забезпечення прав і свобод громадян та правовий режим на тимчасово окупованій території України: Закон Украӥни від 15.04.2014p. № 1207-VII https:/ / zakon. rada.gov.ua/laws/show/1207-18

4. Про особливості державної політики із забезпечення державного суверенітету України на тимчасово окупованих територіях у Донецькій та Луганській областях: Закон Украӥни від 18.01.2018 р. № 2268-VIII https:/ / zakon.rada.gov.ua/laws/show/2268-19

5. Попереджені теракти, засуджені зрадники та протидія корупщії в оборонній сфері - контррозвідка СБУ підбила підсумки роботи за рік. 27.12.2019p. https:/ /ssu.gov.ua/ ua/news/1/category/2/view/6923?fbclid=IwAR2pek1AObqIfs0WZEoLFMZ1n8oqhcejjZfti9I RFZSdcb0yyKJlx_8nIM\#.JGLsDIUO.dpbs

6. Зайцев О. В. До питання державної зради у формі шпигунства (ст. 111 КК Украӥни) // Вісник Луганського державного ун-ту внутріиніх справ імені Е. О. Дідоренка. 2017. № 3 (79). C. $48-58$.

7. Зайцев О. В., Філіпенко В. Р. Надання іноземній державі, іноземній організації або ïx представникам допомоги в проведенні підривної діяльності проти України як форма державної зради (ст. 111 КК України). Вісник Луганського державного університету внутріинніх спраВ імені Е. О. Дідоренка. Северодонецьк, 2019. Вип. 3 (87). С. $244-255$.

8. Збройний конфлікт в Украӥні: військова підтримка незаконних збройних формувань «ДНР» та «ЛНР» $з$ боку Російської Федерації / О. Гарбар, А. Конопкін, О. Кореньков, С. Мовчан, За ред.: О. Павліченка, О. Мартиненка / Украӥнська Гельсінська спілка з прав людини. К., 2018. 40 с.

9. Ухвала колегії суддів судової палати з розгляду кримінальних справ Запорізького апеляційного суду від 22.11.2018 у справі № 319/85/17. URL: http:// reyestr. court.gov. ua/ Review/78161951

10. Постанова Верховного Суду від 05 липня 2018 року у справі № 225/6151/ 15- к, провадження № 51-1609км18 http:/ / www.reyestr.court.gov.ua/Review/75241808

11. Отчет о действиях по предварительному расследованию за 2016 г. Канщелярия Прокурора Международного уголовного суда. 14.11.2016 г. URL: https://www.icc-cpi.int/ iccdocs/otp/161114-otp-rep-PE-Ukraine.pdf

12. Отчет о действиях по предварительному расследованию за 2018 г. Канцелярия Прокурора Международного уголовного суда. 05.12.2018 г. URL: https:/ /www.icc-cpi.int/ itemsDocuments/2018-otp-rep-PE-Ukraine.pdf

13. Report on Preliminary Examination Activities (2019) 5 December 2019. International Criminal Court https://www.icc-cpi.int/Pages/item.aspx?name=191205-rep-otp-PE

14. Ухвала колегії суддів судової палати з розгляду кримінальних справ Апеляційного суду м. Києва від 25.06.2018 у справі № 11-кп/796/431/2018. URL: http:// reyestr. court. gov.ua/Review/75004486 
15,Зайцев О. В. До проблеми кваліфікації державної зради у разі переходу на бік ворога в період збройного конфлікту (аналіз судової практики 2014-2018рр.) Вісник Луганського державного університету внутрішніх справ імені Е. О. Дідоренка. Сєвєродонецьк, 2019. Вип. 2 (86). С. 258-269.

16. Распоряжение Президента Российской Федерации от 16.11.2016 № 361-рп «О намерении Российской Федерации не стать участником Римского статута Международного уголовного суда» Официальный интернет-портал правовой информации http:// publication.pravo.gov.ru/Document/View/0001201611160018

17. Федеральный закон от 12.11.2019 № 368-Ф3 «Об отзыве заявления, сделанного при ратификации Дополнительного протокола к Женевским конвенщиям от 12 августа 1949 года, касающегося защиты жертв международных вооруженных конфликтов (Протокол I)». Официальный интернет- портал правовой информации http:/ / publication.prav o.gov.ru/Document/View/0001201911120051

18. Вирок Дарнищького районного суду м. Києва від 06.02.2018 р., справа № 753/2407 0/16- к, провадження № 1- кп/753/259/18 / / http:/ / reyestr.court.gov.ua/Review/72174943

19. Ухвала Апелящійного суду м. Києва від 12 вересня 2018 року у справі № 753/ 24070/16-к колегія суддів судової палати з розгляду кримінальних справ http:// reyestr. court.gov.ua/Review/76612196

20. Постанова Верховного Суду від 20 червня 2019 року у справі № 753/24070/16 к, п ровадження № 51 - 10318 км 18 http:/ / reyestr.court.gov.ua/Review/82599973

21. Росія надала Україні докази вини 229 кримських прокурорів-зрадників - ГПУ. 30 вересня, 2016 https:/ /tyzhden.ua/News/175083

22. Коваленко О. Як ми втрачали Крим: свідчення перших осіб України 10.04.2017p. https://www.pravda.com.ua/cdn/graphics/2017/04/jak_my_vtrachaly_krym_svidchennja_p ershyh_osib_ukrainy/

23. ГПУ оприлюднила повістки 727 підозрюваним у держзраді 31 травня 2016 // https://www.pravda.com.ua/news/2016/05/31/7110349/

\section{References:}

1. Za 10 rokiv v Ukrayini za derzhavnuzradu zasudy`ly` 7 lyudej. 28.04.2012. URL: http:// tyzhden.ua/News/48897 [in Ukrainian].

2. Skolko «yzmennykov» obnaruzhyla Rodyna № 103, 16.09.2011 URL: https:/ / novayagazeta.ru/articles/2011/09/16/45916- skolko 171-izmennikov-187- obnaruzhila-rodina [in Ukrainian].

3. Pro zabezpechennia prav i svobod hromadian ta pravovyi rezhym na tymchasovo okupovanii terytorii Ukrainy: ZakonUkrainyvid 15.04.2014r. № 1207-VII. URL: https:/ / zakon. rada. gov.ua/laws/show/1207-18 [in Ukrainian].

4. Pro osoblyvosti derzhavnoi polityky iz zabezpechennia derzhavnoho suverenitetu Ukrainy na tymchasovo okupovanykh terytoriiakh u Donetskii ta Luhanskii oblastiakh: Zakon Ukrainy vid 18.01.2018 r. № 2268-VIII URL: https:/ / zakon.rada.gov.ua/laws/show/2268-19 [in Ukrainian].

5. Poperedzheni terakty, zasudzheni zradnyky ta protydiia koruptsii $\mathrm{v}$ oboronnii sferi - kontrrozvidka SBU pidbyla pidsumky roboty za rik. 27.12.2019r. URL: https: // ssu. gov. ua/ua/news/1/category/2/view/6923?fbclid=IwAR2pek1AObqJfs0WZEoLFMZ1n8oqhcejJj Zfti9IRFZSdcb0yyKJlx_8nIM\#.JGLsDIUO.dpbs [in Ukrainian].

6. Zaitsev, O. V. 92017) Do pytannia derzhavnoi zrady u formi shpyhunstva (st. $111 \mathrm{KK}$ Ukrainy) // Visnyk Luhanskoho derzhavnoho un-tu vnutrishnikh sprav imeni E. O. Didorenka-Bulletin of Lugansk State University of Internal Affairs named after E. O. Didorenko. Sievierodonetsk. № 3 (79), 48-58. [in Ukrainian]. 
7. Zaitsev, O. V., Filipenko, V. R. (2019) Nadannia inozemnii derzhavi, inozemnii orhanizatsii abo yikh predstavnykam dopomohy $\mathrm{v}$ provedenni pidryvnoi diialnosti proty Ukrainy yak forma derzhavnoi zrady (st. 111 KK Ukrainy). Visnyk Luhanskoho derzhavnoho universytetu vnutrishnikh sprav imeni E. O. Didorenka-Bulletin of Lugansk State University of Internal Affairs named after E. O. Didorenko. Sievierodonetsk, 3 (87), 244-255. [in Ukrainian].

8. Zbroinyi konflikt v Ukraini: viiskova pidtrymka nezakonnykh zbroinykh formuvan «DNR» ta «LNR» z boku Rosiiskoi Federatsii (2018) O. Harbar, A. Konopkin, O. Korenkov, S. Movchan (Eds.) O. Pavlichenk, \& O. Martynenk (Ed.) Ukrainska Helsinska spilka z prv liudyny. Kyiv. [in Ukrainian].

9. Ukhvala kolehii suddiv sudovoi palaty $\mathrm{z}$ rozghliadu kryminalnykh sprav Zaporizkoho apeliatsiinoho sudu vid 22.11.2018 u spravi № 319/85/17. URL: http:// reyestr. court.gov.ua/ Review/78161951 [in Ukrainian].

10. Postanova Verkhovnoho Sudu vid 05 lypnia 2018 roku u spravi № 225/6151/15k, provadzhennia № 51 1609km18 URL: http:/ / www.reyestr.court.gov.ua/Review/75241808 [in Ukrainian].

11. Otchet o deistvyiakh po predvarytelnomurassledovanyiu za 2016h. Kantseliaryia Prokurora Mezhdunarodnohouholovnohosuda. 14.11.2016 h. URL: https://www.icc-cpi.int/ iccdocs/otp/161114-otp-rep-PE-Ukraine.pdf [in Ukrainian].

12. Otchet o deistvyiakh po predvarytelnomurassledovanyiu za 2018h. Kantseliaryia Prokurora Mezhdunarodnohouholovnohosuda. 05.12.2018h. URL: https://www.icc-cpi.int/ itemsDocuments/2018-otp-rep-PE-Ukraine.pdf [in Ukrainian].

13. Report on Preliminary Examination Activities (2019) 5 December 2019. International Criminal Court. URL: https:// www.icc cpi.int/Pages/item.aspx?name=191205-rep-otpPE [in Ukrainian].

14. Ukhvala kolehii suddiv sudovoi palaty z rozghliadu kryminalnykh sprav Apeliatsiinoho sudu m. Kyieva vid 25.06.2018 u spravi № 11-kp/796/431/2018. URL: http:// reyestr.court.gov.ua/Review/75004486 [in Ukrainian].

15. Zaitsev, O. V. (2019) Do problemy kvalifikatsii derzhavnoi zrady u razi perekhodu na bik voroha v period zbroinoho konfliktu (analiz sudovoi praktyky 2014-2018 rr.) Visnyk Luhanskoho derzhavnoho universytetu vnutrishnikh sprav imeni E. O. Didorenka-Bulletin of Lugansk State University of Internal Affairs named after E. O. Didorenko. Sievierodonetsk, 2 (86), 258-269. [in Ukrainian].

16. Rasporiazhenye Prezydenta Rossyiskoi Federatsyy ot 16.11.2016 № 361-rp «O namerenyy Rossyiskoi Federatsyy ne stat uchastnykom Rymskoho statuta Mezhdunarodnoho uholovnoho suda» Ofytsyalnyi ynternet- portal pravovoi ynformatsyy. URL: http:/ / publicatio n.pravo.gov.ru/Document/View/0001201611160018 [in Ukrainian].

17. Federalnyi zakon ot 12.11.2019 № 368-FZ «Ob otzyve zaiavlenyia, sdelannoho pry ratyfykatsyy Dopolnytelnoho protokola k Zhenevskym konventsyiam ot 12 avhusta 1949 hoda, kasaiushchehosia zashchyty zhertv mezhdunarodnykh vooruzhennykh konflyktov (Protokol I)». Ofytsyalnyi ynternet portal pravovoi ynformatsii. URL: http://publication.pravo.gov.ru/ Document/View/0001201911120051 [in Ukrainian].

18. Vyrok Darnytskoho raionnoho sudu m. Kyieva vid 06.02.2018r., sprava № 753/ 24070/16-k, provadzhennia № 1 kp/753/259/18 URL: http:/ / reyestr.court.gov.ua/Review/7 2174943 [in Ukrainian].

19. Ukhvala Apeliatsiinoho sudu m. Kyieva vid 12 veresnia 2018 roku u spravi № 753/ 24070/16-k kolehiia suddiv sudovoi palaty z rozghliadu kryminalnykh sprav. URL: http:// reyestr.court.gov.ua/Review/76612196 [in Ukrainian].

20. Postanova Verkhovnoho Sudu vid 20 chervnia 2019 roku u spravi № 753/ 24070/16 k, provadzhennia № 51 - 10318 km 18. URL: http://reyestr.court.gov.ua/Review/82 599973 [in Ukrainian]. 
21. Rosiia nadala Ukraini dokazy vyny 229 krymskykh prokuroriv-zradnykiv - HPU. 30 veresnia, 2016. URL: https://tyzhden.ua/News/175083 [in Ukrainian].

22. Kovalenko, O. Yak my vtrachaly Krym: svidchennia pershykh osib Ukrainy 10.04.2017r. URL: https: //www.pravda.com.ua/cdn/graphics/2017/04/jak

myvtrachaly_krym_svidchennja_pershyh_osib_ukrainy/ [in Ukrainian].

23. HPU opryliudnyla povistky 727 pidozriuvanym u derzhzradi 31 travnia 2016. URL: https://www.pravda.com.ua/news/2016/05/31/7110349/ [in Ukrainian].

Стаття надіӥшла до редколегіï 12.02.2020

Зайцев А. В.,

кандидат юридических наук, доцент, доцент кафедры уголовного права № 1

Национального юридического университета

Украины имени Ярослава Мудрого

(г. Харьков, Украина)

\section{ПРОБЛЕМЫ КВАЛИФИКАЦИИ ГОСУДАРСТВЕННОЙ ИЗМЕНЫ НА СОВРЕМЕННОМ ЭТАПЕ}

В результате изучения судебной практики Кассационного уголовного суда в составе Верховного Суда сделан вывод о разной уголовно-правовой оценке вооруженных конфликтов на территории Украины. Это повлекло применение ст. 111 УК Украины, в одном случае, и ст. 258-3 УК Украины - в другом. Уделено внимание международной правовой оценке вооруженных конфликтов на территории Украины. Отмечается исключительное значение производств в Международном уголовном суде, результаты которых способны повлиять на разрешение проблем квалификации государственной измены.

Ключевые слова: государственная измена, вооружённый конфликт, Международный уголовный суд.

Zaytsev O., Candidate of Law, Associate Professor, Associate Professor of the Department of Criminal Law № 1

National Law Universitynnamed after Yaroslav Mudriy (Kharkiv, Ukraine)

\section{PROBLEMS OF HIGH TREASON QUALIFICATION ON THE CURRENT STAGE}

As a result of the examination of the case law for high treason, it is concluded that there is a different assessing the criminal justice of armed conflicts in the territory of Ukraine. Courts point out that there is the absence of international armed conflict in eastern Ukraine, in contrast to the signs of its presence in the Crimea. This entails the application of the article 111 of the Criminal Code of Ukraine in one case and the article 258-3 of the Criminal Code of Ukraine in another one.

The article notes the importance of the proceedings of the International Criminal Court, whose decision may affect the solution of problems of qualification of high 
treason. To date, the Prosecutor's Office is considering an alternative to defining an armed conflict in eastern Ukraine. It is a question of the possibility of applying the provisions of the Rome Statute concerning both international and non-international armed conflict. The situation on the territory of the Crimea is qualified as an international armed conflict between Ukraine and Russia, which arose no later than on 26 February 2014 and continues the occupation of the peninsula.

Also, the defendants for high treason cite their lack of Ukrainian citizenship in the transition to Russia during the armed conflict in February 2014. As the main argument is the Decree of the President of Ukraine "On withdrawal from the citizenship of Ukraine", signed by V. F. Yanukovych. Such documents are not recognized by the bodies of state power of Ukraine as official, which leads to recognition by the court of such persons as subjects of high treason.

The most controversial problems could be solved by the International Criminal Court, which would establish the existence or absence of armed conflicts in the territory of Ukraine, their nature, parties, period of existence and other legal consequences. At the same time, participants in criminal proceedings, choosing and applying the provisions of Ukraine on criminal responsibility on high treason, should take into account the existing conclusions of the Court of Cassation, as set out in the decisions of the Supreme Court.

Keywords: state treason, armed conflict, International Criminal Court.

DOI: $10.33766 / 2524-0323.89 .89-101$

УДК 342.7

О. А. Любчик,

доктор юридичних наук, доцент, професор кафедри державно-правових дисциплін Луганського державного університету внутрішніх справ імені Е. О. Дідоренка

(м. Сєвєродонецьк, Україна)

e-mail: lyubchikaa@gmail.com

iDhttps:/ / orcid.org/0000-0002-8239-2129

\section{«ГРА СЛІВ» 3 ТЯЖКИМИ НАСЛІДКАМИ, АБО ЩО ТАКЕ МЕДИЧНА ДОПОМОГА}

У статті досліджуються сутність, ознаки та визначення поняття «медична допомога» як юридично значущого терміна, співвідношення цього поняття 3 поняттям «медична послуга». Досліджуються правові позищією законодавця і Конституційного Суду України з цього приводу та ставлення до цього питання науковців. Проведений порівняльний аналіз правової природи термінів «медична допомога» та «медична послуга». Визначається стан і тенденщії правового регулювання захисту прав людини на здоров'я та життя в Україні. Запропоновані напрямки вдосконалення правового регулювання щодо захисту прав людини на здоров'я та життя.

Ключові слова: медична допомога, медична послуга, захист прав людини на здоров'я та життя, тенденції правового регулювання, законодавче забезпечення захисту прав людини.

() Любчик О. А., 2020 